\title{
Developing English learning materials for computer network engineering students at peripheral Indonesia
}

\author{
Andri Prayoga, Dedi Irwansyah*, Trisna Dinillah Harya \\ English Language Education Department, State Islamic Institute of Metro, Indonesia
}

\author{
*Corresponding Author \\ Email: dedi.irwansyah@metrouniv.ac.id
}
Received:
Revised:
Accepted:
Published:
13 May 2020
26 January 2021
27 February 2021
28 February 2021

\begin{abstract}
This research was aimed at developing and validating English learning materials for students of computer network engineering of Vocational High School (VHS) at peripheral city of Indonesia. This study followed the Research and Development (R\&D) method. It involved three experts in the field of English instruction, ten students and one English teacher of Vocational High School (VHS) Teladan Metro, Lampung which was considered as a peripheral part of Indonesia. The research data were drawn from questionnaire distributed to the students, an interview conducted to the English teacher, and the developed materials which had been validated by the experts. The findings of the research show: (1) the development of English learning materials for computer networking should be centred around the students' learning needs; (2) a prompting visuals aspect and a clear map of the course book are what make the developed course book more acceptable, and (3) experts validation of the developed course book enhances its readability and acceptability. It is recommended that English teachers of VHS would design their own supplementary learning materials as the nation-wide use materials might not cover all of the students' learning needs.
\end{abstract}

Keywords: ELT; learning material; vocational high school; computer network engineering

\section{INTRODUCTION}

A commercially developed learning material might not perfectly suit the needs of a particular learning situation (McDonough, Shaw, \& Masuhara, 2013). Developing learning materials that involves teacher, students, and experts through a research and development scheme should give added value to the developed learning materials itself. Tomlinson (2005) urges that materials should be matched to the context of learning. The researchers find that English learning materials for students of computer network engineering of Vocational High School (VHS) Teladan of Metro needs to be matched to suit the real needs of students and teachers. The writers argue that every context 
of learning, including VHS Teladan of Metro, is unique in that a researchbased learning material is needed.

So far, the discussion of the learning materials tends to follow three tendencies. First, English learning materials is discussed in its correlation with character education (Amrina \& Anom, 2020; Islami, 2016; Kristiyani, 2013; Pohan, 2014; Ratih, 2017; Thresia \& Metro, 2014). Second, English learning materials is developed within the framework of English for specific purposes (Fadliah \& Sugirin, 2019; Klimova, 2015; Puspita, 2018; Ratnawati, 2018; Trisyanti, 2009). Third, English learning materials is developed to strengthen one language skill or language mastery (Hidayat, 2017; Karman, 2017; Sukirman, 2015; Taridi, 2019; Umam, 2015; Yana, 2016). The above tendencies make it clear that English learning materials for students of computer network engineering of VHS has been rarely discussed let alone in a peripheral city of Indonesia. It creates a gap encouraging material designers to develop a teaching materials fot the computer network engineering students.

This paper is aimed at fulfilling the aforementioned gap by specifically developing an English course material for the students of computer network engineering of VHS Teladan of Metro, Lampung, Indonesia. Three research questions are formulated as follow: (1) what are the learning needs of the computer network engineering students of VHS Teladan of Metro? (2) What the English learning materials for the computer network engineering students of VHS Teladan Metro is like? and (3) what is the internal validity of the developed English learning materials? To support the study, a brief review of literature is presented below.

\section{Teaching English at vocational high school}

The teaching of English in vocational high schools is not that different from that of senior high schools in the sense that it is aimed at developing the four basic skills of English. Nevertheless, it is obvious that English learning materials for vocational high schools should be distinctive. The materials should be designed provide the students with the skills and knowledge required in the industrial world besides to reach the higher education level. The explanations above show that teaching English in vocational high school is such unordinary matter (Apriyandini \& Rochsantiningsih, n.d.), in the sense that it requires a strong needs analysis on the students' language level and prior learning experience as well as texts and activities.

In some vocational high schools, the speaking materials and the purpose of speaking instruction are developed in accordance with the English teachers' creativity. The teachers ponder that the materials should match the students' competencies to their future possible jobs (Ririn \& Muflikhatun, 2018). The teaching process in each program of vocational high school is demanded to comply the student outlook since the main target of vocational high school is focused on education and training program at the bordered area of proficiency. Thereupon specifying the content of English learning is entailed. The output is that the English for specific purpose (ESP) becomes a big crucial matter in the flow of vocational high school teaching learning hence ESP is a solution to complete the particular goals (Dewi, 2015). Accordingly, the goals should be designed in line with the target needs and the learning needs. The former 
pertains to what the learners need to do in the target situation. The latter refers to what the learners need to do in order to learn.

\section{Materials development}

Development refers to any positive and admissible activities. The gradual activities executed by a person or some officials that have working plan schemes to obtain betterment or profitable conditions in both policies and investments are the reason why development takes places (Bellu, 2011). The scope of ESP courses is smaller compare to the common ELT courses. ESP course centralizes neither on personal needs or general interests but is more on the work or study related needs (Basturkmen, 2010). The development of English learning materials should not be directed toward the native speaker's proximity or correctness but rather to the authentic use of English itself and to the communicative skills (Kiczkowiak, 2019). To develop an effective teaching materials, a developer needs to consider various factors such as teachers' expertise, teachers' training experience, students' cultural background, preferable teaching style, type of study expected by the learner, the students' learning necessities, the readability and motivation of the learner. Another factor to be considered is the so-termed contextual factor which deals with school culture, the circumstance of the class, and the existence of teaching resources in which the materials are implemented (Richards, 2006).

Sumarsono, Wardhani, \& Farah (2017) argue most of vocational high schools do not provide the apprentices with the appropriate textbooks which are reliable and research-based. The rare of the textbook itself may become the greatest factor causing the vocational high schools lacks of written resource. Eventually, many of graduated pupils of vocational high school are weak in communication and many of them are rejected or fail to complete the requirement of vacancy requiring English skill. Developing the ESP course whether online or face to face, the composer is not allowed to disregard the three principal stages as taking these steps will bring the possibility for the designer to construct the ESP learning material in accordance with target learner necessities. The first step is analyzing the needs of the student to decide the goals of the course. The next step is determining the teaching theory and the last is adjusting the authentic text to assign proper teaching materials (Bielousova, 2017). Contemplating the language teaching principles are the certainty to develop classroom materials. The needs and the wants of the apprentices have to be fulfilled by the teaching; it is the core of teaching principles. The most important principle of developing materials is that the teachers are able to apply the written materials as reference instead of rigid provision (Tomlinson, 2010).

Derived from the statements above, it is safe to argue that to develop the teaching and learning materials require some aspects to be thought over. Those aspects are; the necessities and the expectation of the pupils, the proficiency of the teacher, the availability of the resource, and the contextual factors. The product of the research should be in a form of authentic forms to support the learning process. 


\section{Activity and task}

The students' expectations of the input are specified by the activities. Besides, the basic essence of the learning is also influenced by the will of the students. Before inspecting several particular activity examples the teachers have to indicate the three regular ways of characterizing activities such as the practice for the real world, skills use, and fluency or accuracy (Nunan, 2010). Activities are something assisting the learners to work out with peculiar case whether linguistic, encyclopedic, transfer or professional. Consequently activities are conceived as a tangible and concise exercise (Georgiou \& Pavlou, 2003).

Literally there are two kinds of activity; the activity regarding to body movement to encode or decode the communication signal (Psycho-motor Activity) and the activity of processing the information from what is heard, read, spoken and written (Processing Activity) (Chamberlain \& Baumgardener, 1998). The communicative language teaching is highly influenced by the tasks. In practicing the elements of language presented through more traditional tools (task supported teaching), the task can be empowered as a source that provides context while in introducing new content (task based teaching), the task is the only instrument that is possible to use (Jendrych \& Wisniewska, 2010.). Evaluating related activities to answer the call of communicative ESP elements becomes a crucial thing throughout the circulation of the task. Since the activities support the students to extend the communicative proficiency within the range of real-life state and authenticity, as it has been investigated, it can be used for fulfilling the gap of the tasks (Villanea Morales, 2018). Task means the whole activities enabling the students to practice the target language in order to get the learning outcomes. Task can be divided into six parts namely: (1) listing; (2) ordering and sorting; (3) comparing; (4) problem solving; (5) sharing personal experience; and (6) creative tasks (Wilis, 2005).

In line with the explanation above, the appropriate activities and tasks will bring a great impact on the learners' learning English point of view. It reduces the learners' mindsets that English is difficult and boring. The teacher's roles are not only about presenting and explaining the materials but also designing the syllabus, preparing the material. The teachers must be really careful in designing the activity by considering the needs of the learners both psychological needs and academicals field needs.

\section{Assessment}

According to Ÿelik and Topkaya (2016), there is no a good teaching with no evaluation in it. The lack of instrument to evaluate the course becomes a big problem in teaching. Assessment in the form of summative and formative is possibly utilized to evaluate the learners understanding, how excellent the learner practices the material, what is their strength and weakness, what suggestion the learners need and how match the materials to their need (Graves, 2000).

The importance of evaluating in improving both general courses and ESP is not questionable, especially in terms of continuous improvement (Çelik, 2018). To strengthen synchronization between learning and the needs of students and also the goals of students, evaluations that are integral components of learning are considered important to be evaluated (Karimnia \& 
Jafari, 2017). Test, measurement, and evaluation are three interlinked activities that play a very important role in the success of ESP learning. There are several factors that need to be evaluated so that ESP has a significant impact on learners. These factors include psychological stability and available resources (Siddiqui, Illyas, \& Jokhio, 2017). Within the material development, evaluation and assessment are needed to ensure that the developed learning materials meets the target of the course (Utami, 2019).

Assessment is performed via several instruments both formal and informal. It is a term employed to accumulate the whole method of gathering information about apprentices understanding, knowledge, skills, behavior and motivation (Georgiou \& Pavlou, 2003).English is delivered by the educator with the expectation that the students' comprehension and the capability to express are advanced. Therefore, evaluation is confirmed notable in English language teaching (Patel \& Jain, 2008).Evaluation, assessment and testing affect one another in education system and they can be implemented whenever the time is and wherever the place is within the curriculum boundaries (Nunan, 2010).

\section{METHOD}

\section{Respondents}

The data was obtained from both students and English teacher of VHS Teladan Metro. The population of this research was 25 students yet 10 students became the research sample. A questionnaire of needs analysis was distributed to the research sample while an interview was conducted with one English teacher of VHS Teladan Metro. An internal validation was administered involving three related experts in the field.

\section{Instruments}

This study used three different instruments in order to achieve its objectives namely: interview, product evaluation sheet, and focus group discussion. The instruments are mainly applied to gain the information about the students' learning needs and to measure the product validity. Table 1 displays the research instruments and the research stages.

Table 1. The stage and the instrument

\begin{tabular}{lll}
\hline No. & Stages & Research Instrument \\
\hline 1. & Planning & Questionnaire and interview guide \\
2. & Validating & Product evaluation sheet \\
3. & Revising & Focus group discussion sheets \\
\hline
\end{tabular}

The questionnaire consists of 18 statements related to the students' perception and expectation of the English materials for vocational high schools. It applies Likert scale with five scales ranging from strongly agree to strongly disagree. The product evaluation sheet was used to gain information related to the title suitability, size conformity, language and vocabulary, material compatibility, material depth, material accuracy, material update, students' development level, communication aspect, accuracy, coherency and unity, presentation, layout, illustration, and typography. The focus group 
discussion was used to gain information related to the suggestions needed to upgrade the developed learning materials in this study.

\section{Procedures}

The research procedure in this study adopts Sugiyono's (2015) R \& D first level model as follow: (1) Planning. This phase was conducted by investigating the students' needs through the questionnaire and interview; (2) Developing the preliminary form of the educational product. This phase deals with composing the course book units in accordance with the students' needs; (3) Validating. This process involved three experts or validators to score the developed product; and (4) Revising. This phase was conducted after the developed product being validated by three experts. It was based on the experts' suggestion that the product was then revised.

\section{Data analysis}

The data of this study included qualitative data and quantitative data. The qualitative data were collected in the planning and revising stages of the study through questionnaire and interview. The qualitative data were analyzed following six main steps: preparing and organizing the data, reviewing and exploring the data, coding the data, constructing description, building themes, and interpreting the data (Lodico, Spaulding, \& Voegtle, 2010). Meanwhile, the quantitative data which were collected during the validating phase through evaluation sheet were then analysed using Aiken's $\mathrm{V}$ formula. The formula was used to determine the content-validity coefficient of a measurement conducted by several experts. The coefficient value of Aiken's V ranges from 0 to 1 , in that the value of 0.5 or higher is considered to have reached an adequate content validity (Hendryadi, 2014) .

\section{RESULTS AND DISCUSSION}

\section{The learning needs of the computer network engineering students of VHS}

Analysis of students' learning needs should be an important stage in developing the learning materials in a peripheral Indonesian school. It is assumed that a proper analysis of students' learning needs serves as a stepping stone to an acceptable and contextual developed learning material. Table. 2 displays the participants' perception of the existing English learning materials and their expectation of a particular developed materials.

Table 2. Students' perception and expectation of the English materials

\begin{tabular}{|c|c|c|c|c|c|c|}
\hline \multirow[t]{2}{*}{ No. } & \multirow[t]{2}{*}{ Statement } & \multicolumn{5}{|c|}{ Score } \\
\hline & & 1 & 2 & 3 & 4 & 5 \\
\hline 1 & $\begin{array}{l}\text { The recent English course book is less correlated to the } \\
\text { field of computer network engineering. }\end{array}$ & $0 \%$ & $0 \%$ & $10 \%$ & $80 \%$ & $10 \%$ \\
\hline 2 & $\begin{array}{l}\text { English lesson within VHS must be adjusted to the field } \\
\text { of computer network engineering. }\end{array}$ & $0 \%$ & $0 \%$ & $20 \%$ & $70 \%$ & $10 \%$ \\
\hline 3 & English course book supports the study. & $0 \%$ & $0 \%$ & $0 \%$ & $50 \%$ & $50 \%$ \\
\hline 4 & $\begin{array}{l}\text { English course book looks more attractive with some } \\
\text { pictures. }\end{array}$ & $0 \%$ & $0 \%$ & $20 \%$ & $50 \%$ & $30 \%$ \\
\hline
\end{tabular}




\begin{tabular}{|c|c|c|c|c|c|c|c|}
\hline 5 & $\begin{array}{l}\text { The learning topic must } \\
\text { computer network engineeri }\end{array}$ & isted to the field of & $0 \%$ & $0 \%$ & $50 \%$ & $50 \%$ & $10 \%$ \\
\hline 6 & $\begin{array}{l}\text { Some proverbs and interes } \\
\text { course book. }\end{array}$ & ct are needed in the & $0 \%$ & $0 \%$ & $10 \%$ & $70 \%$ & $20 \%$ \\
\hline 7 & $\begin{array}{l}\text { A good English course book } \\
\text { study independently. }\end{array}$ & enable the student to & $10 \%$ & $0 \%$ & $10 \%$ & $60 \%$ & $20 \%$ \\
\hline 8 & A colorful English course bo & hore interesting. & $0 \%$ & $0 \%$ & $40 \%$ & $50 \%$ & $10 \%$ \\
\hline 9 & Formal fonts demotivate you & idy. & $0 \%$ & $40 \%$ & $10 \%$ & $40 \%$ & $10 \%$ \\
\hline 10 & Vocabulary list ease the stuc & understand the text. & $0 \%$ & $20 \%$ & $10 \%$ & $60 \%$ & $10 \%$ \\
\hline 11 & The learning material is avai & or practice. & $0 \%$ & $10 \%$ & $20 \%$ & $70 \%$ & $0 \%$ \\
\hline 12 & The multiple choice exercise & sting. & $0 \%$ & $0 \%$ & $10 \%$ & $80 \%$ & $10 \%$ \\
\hline 13 & The essay exercise is needed & course book. & $0 \%$ & $10 \%$ & $10 \%$ & $60 \%$ & $20 \%$ \\
\hline 14 & The filling the blank is attrac & xercise. & $0 \%$ & $10 \%$ & $10 \%$ & $80 \%$ & $0 \%$ \\
\hline 15 & $\begin{array}{l}\text { The exercise is more fun in } \\
\text { random sentence/phrase }\end{array}$ & $\mathrm{rm}$ of rearranging the & $0 \%$ & $0 \%$ & $30 \%$ & $70 \%$ & $0 \%$ \\
\hline 16 & Some games are needed in $\mathrm{E}$ & learning. & $10 \%$ & $0 \%$ & $20 \%$ & $20 \%$ & $50 \%$ \\
\hline 17 & True and false exercise is int & ig to do. & $0 \%$ & $10 \%$ & $20 \%$ & $80 \%$ & $0 \%$ \\
\hline 18 & $\begin{array}{l}\text { The English learning materia } \\
\text { future carrier needs. }\end{array}$ & ald support your & $0 \%$ & $0 \%$ & $0 \%$ & $70 \%$ & $30 \%$ \\
\hline \multicolumn{8}{|c|}{ Remarks: } \\
\hline & : Strongly Agree & \\
\hline & : Agree & & & & & & \\
\hline & : Neutral & : Strongly Disagree & & & & & \\
\hline
\end{tabular}

Table 2 displayed the students' statement of belief that the availability of a suitable English learning materials would support their learning. Unfortunately, the existing commercially published learning materials did not completely fit the students' needs in the field of computer network engineering. All participants of the study suggested for learning materials adjustment. The developed learning materials should be equipped with more attractive pictures compared to those in the existing materials. The topics discussed in the developed learning materials should closely relate to the field of computer network engineering. To inculcate values into the English instruction in the computer network engineering, the addition of motivating proverbs into the units will be useful. Above all, the participants of the study expected to have a more colourful and practical English learning materials which was equipped with vocabulary list, attractive exercises, games, informative texts.

A total of $50 \%$ of the students involved in the study obviously need the English course book to guide their study. However, English learning materials in VHS Teladan Metro is not in line with their field of study. There is no doubt that the students need the English learning materials be specified according to computer network engineering field. The learning topic within the course book must be familiar with computer network engineering field. The students demand the book which can lead them to have a self-study. In addition, most students felt lack of vocabularies in that they could not understand the given text and task easily. To overcome this matter, the students need vocabulary list to support the process in understanding the text. Language is about applying the language; which in this case the students need the learning materials to be applicable. It can be stated that most of the students need an 
English learning materials which can be applied in the future profession especially in computer network engineering field.

The findings of this study support the idea of using appropriate learning materials as an important part of instructional strategies that ought to be noticed by teachers of English to computer science within Indonesian context (Lestariningsih, Madya, \& Nurkamto, 2020). The findings are also in tune with the notion stating that such visual aspects of learning materials as font size, layout, and illustration as well as glosses or vocabulary lists are among the factors that make a learning materials acceptable (Irwansyah, 2019). Thus, the results of the learning needs analysis of this study are in line with existing relevant researches.

\section{The learning materials for the computer network engineering students of VHS}

Based on the learning needs analysis, a course book is carefully developed to respond the results of the learning needs analysis. The developed course book might not accommodate the needs of students of VHS in all parts of Indonesia, yet it fits the need of VHS Teladan Metro, Lampung, a research setting which is considered as a peripheral part of Indonesia. The developed course book is a pilot project in nature for it consists of three units only. Table 3. the map of the developed course book.

Table 3. The map of the developed course book

\begin{tabular}{|c|c|c|c|c|c|}
\hline No. & Unit & Title & Skill & Activities & Taxonomy \\
\hline 1. & $\begin{array}{l}\text { Unit } \\
\text { One }\end{array}$ & Windows & Reading & $\begin{array}{l}\text { - Brainstorming } \\
\text { - Analyzing sentence } \\
\text { - Word organizing } \\
\text { - Rearranging a paragraph } \\
\text { - Answering questions } \\
\text { based on the paragraph }\end{array}$ & LOTS \\
\hline 2. & $\begin{array}{l}\text { Unit } \\
\text { Two }\end{array}$ & Bill Gates & Reading & $\begin{array}{l}\text { - Acknowledging the } \\
\text { personality of the main } \\
\text { character within this } \\
\text { chapter } \\
\text { - Rearranging the } \\
\text { paragraph } \\
\text { - Explaining the word } \\
\text { - Filling the crossword } \\
\text { - Filling the blank }\end{array}$ & LOTS \\
\hline 3. & $\begin{array}{l}\text { Unit } \\
\text { Three }\end{array}$ & Anonymous & Reading & $\begin{array}{l}\text { - Brainstorming } \\
\text { - Word organizing } \\
\text { - Analyzing sentence } \\
\text { - Answering questions } \\
\text { based on the paragraph } \\
\text { - Summarizing }\end{array}$ & HOTS \\
\hline
\end{tabular}

As table 3 depicts, the texts used in the course book should contain information that directly relate to computer network engineering such as the types of Windows, the lessons from Bill Gate's life, the anonymous in cybercrime. The developed course book is focused on the development of reading skills so as to make it in line with the needs of VHS Teladan Metro Lampung. It is supported by ten types of activities underpinned by both low 
order thinking skills (LOTS) and high order thinking skills (HOTS). In addition, prompting visuals in the form of pictures are also provided to enhance the acceptability of the developed materials. Figure 1. displays the examples of the picture used in this research and development.

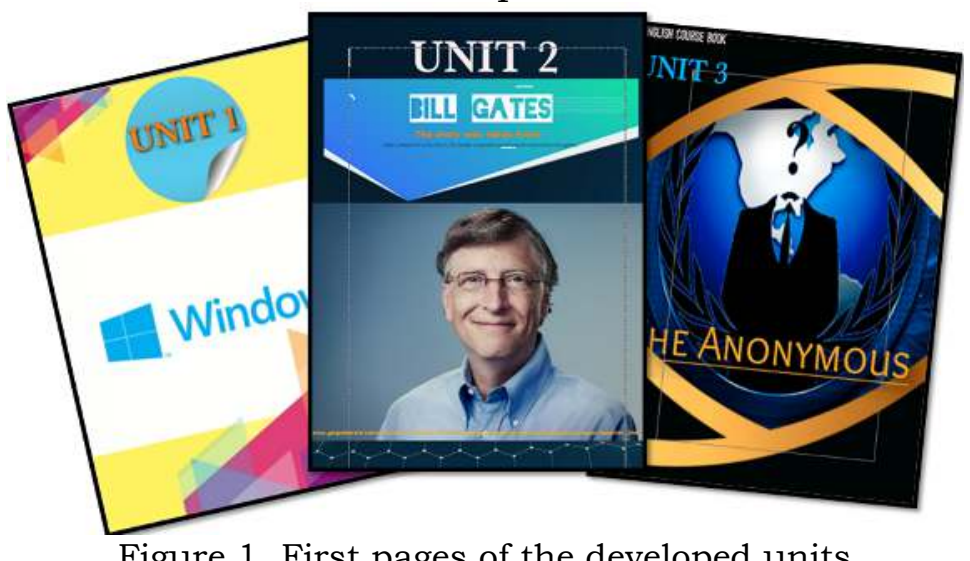

It is apparent from Figure 1 that visual aspects should contain information that help students guess the content of the forthcoming texts. Prompting visuals might alternatively refer to symbols representing computer's brand, photograph of famous person, or illustration of topics being discussed. Besides providing initial information of the text, the visuals are also aimed at enhancing the students' enthusiasm for reading the given texts. It is worth noting that the visuals should be designed in accordance with the students' desire and should be relevant to the students' educational setting.

The results of this study lend partial support to McDonough, Shaw, \& Masuhara's (2013) theory stating that the characteristics of the students and the educational setting are among the primary factors to be considered in constructing syllabus and designing learning materials. The results also confirm the theories of Tomlinson \& Masuhara (2018) as using visuals in learning materials had a positive impact on the instructional activities. Accordingly, the visuals should be used to introduce context or the setting, provoke thoughts and reaction, and encourage students' curiosity and interest. The visuals designed in this study are appropriate for the students of VHS Teladan Metro Lampung. For the use in other educational settings, an adaptation might be needed.

\section{The internal validity of the developed learning materials}

The validation was conducted on 9 September 2019. It involved three English experts. The course book which had been validated and scored was processed by using Aiken's V formula to measure the cogency level. The summary of the Aiken's V result is presented in Table 4. 
Table 4. The Aiken's V recapitulation result

\begin{tabular}{clcc}
\hline No. & Assessment Criteria & Aiken's V & Category \\
\hline 1. & Title suitability & 0.833 & Valid \\
2. & Size conformity & 0.833 & Valid \\
3. & Language and vocabulary & 0.667 & Valid \\
4. & Material compatibility & 0.583 & Valid \\
5. & Material depth & 0.667 & Valid \\
6. & Material accuracy & 0.667 & Valid \\
7. & Material update & 0.833 & Valid \\
8. & Conformity with the level of & 0.500 & Valid \\
& development of students & & \\
9. & Communication & 0.583 & Valid \\
10. & Accuracy & 0.583 & Valid \\
11. & Coherency and unity of ideas & 0.583 & Valid \\
12. & Presentation technique & 0.750 & Valid \\
13. & Presentation of learning & 0.667 & Valid \\
14. & Content layout & 0.750 & Valid \\
15. & Content illustration & 0.667 & Valid \\
16. & Typography of material & 0.667 & Valid \\
\hline
\end{tabular}

As shown in Table 4 the assessment criteria with the score of $>0.500$ is considered valid. The criteria of $<0.500$ is remarked invalid or need to be revised. The average score among the 16 criteria is 0.677 . The title suitability and size conformity obtain the highest point among others, the score is 0.833 . The lowest score is 0.583 , the criteria belonging to this lowest score are; (1) materials compatibility, (2) material conformity, (3) materials communication, (4) materials accuracy and (5) materials coherency and unity of idea. Nevertheless, the Aiken's V value of 0.500 or higher still shows a high contentvalidity coefficient 0.500 (Hendryadi, 2014).

In line with the table above there is no assessment criteria $<0.500$. One point which is worth noting is that the course book is highly acceptable. Nevertheless, those lowest scored criteria become the important consideration for the further research. Although the overall scores surpass the minimum passing grade, the experts as the validators had put some notes according to the gap found during the internal validity.

The first expert suggested to adapt the language according to the capability of the apprentices, simplify the material and decide the targeted readers. The second expert 2 demanded to revise the typography of the materials, grammar and references. The validators also suggest simplifying the text and adapting the text by using the familiar words. The third expert advised to add how and why questions to stimulate the student elaboration skill, use updated materials related to computer network engineering field, add illustration to describe the difficult vocabularies and simplify the reading passages or questions.

As the course book developed in this study has passed through four primary stages of the research and development (planning, developing, validating, and revising), it is safe to state that the course book fit the students' needs in VHS Teladan Metro Lampung. 


\section{CONCLUSION}

This study concludes that a nation-wide produced and used English learning materials will not suit all the needs of the VHS students. A VHS located in peripheral area of Indonesia like VHS Teladan Metro has its own needs related to the English course materials for the students of computer network engineering. To cope with such needs, an English practitioner could develop the materials through three stages namely planning, validating, and revising. The planning stage provides information pertaining to what the material should be so that the learners could learn better. The validating stage gives the material developer insights related to the substantial and practical aspects of the developed materials. In this regard, this study suggests the involvement of at least three experts to validate the developed educational product. It is obvious that the more experts involved, however, the more reliable the educational product would be. The revising stage helps the material developer improves the learning materials after it was implemented. The revising stage of this study confirms that. The students' needs serve as the centre of the learning materials development. The material should be equipped with a prompting visual aspect and a clear map providing the information of units, titles, skills, activities, and taxonomies. While the developed learning material has been carefully planned, developed, validated, and revised, it is worthy of note that it is not aimed at replacing the existing nation-wide used learning materials. Rather, it should be used as a supplementary learning material. It is recommended that other vocational high schools would design their own English materials of computer networking so that they could accommodate the particularity of the students' needs.

\section{REFERENCES}

Amrina, H. N., \& Anom, L. (2020). Developing English materials based on character building for management class in STIE Cendekia. Jo-ELT (Journal of English Language Teaching) Fakultas Pendidikan Bahasa \& Seni Prodi Pendidikan Bahasa Inggris IKIP, 6(2), 69. https://doi.org/10.33394/jo-elt.v6i2.2357.

Apriyandini, D., \& Rochsantiningsih, D. (2016). An analysis of English teaching strategies at vocational high school of art. Unpublished master's thesis. English Education Department Teacher Training and Education Faculty. Sebelas Maret University .

Basturkmen, H. (2010). Developing courses in English for specific purposes. Palgrave Macmillan.

Bellu, L. (TCSP). (2011). Development and Development Paradigms: A (Reasoned) Review of Prevailing Visions. FAO.

Bielousova, R. (2017). Developing materials for English for specific purposes online course within the blended learning concept. TEM Journal, 6(3) https://doi.org/10.18421/tem63-28.

Çelik, H. (2018). A closer look into an ESP course through students' end-of-course evaluations: A case study. Journal of Teaching English for Specific and Academic Purposes, 6(1), 125. https://doi.org/10.22190/JTESAP1801125C. 
Chamberlain, D., \& Baumgardener, R. J. (1998). ESP in the classroom practice and evaluation. Modern English Publications in association with The British Council.

Dewi, S. U. (2015). Syllabus of vocational high school based on ESP approach. Dinamika Ilmu, 15(2), 273. https://doi.org/10.21093/di.v15i2.73.

Fadliah, U., \& Sugirin. (2019). Developing English speaking materials for nursing students. https://doi.org/10.2991/iccie-18.2019.87.

Georgiou, S. L., \& Pavlou, P. (2003). Assessing young learners. Oxford University Press.

Graves, K. (2000). Designing language courses: A guide for teachers (D. Freeman, ed.). Heinle\&Heinle.

Hendryadi. (2014). Content validity. Teorionline Personal Paper, (1), 1-5.

Hidayat, N. (2017). Developing e-reading materials for students at grade seven. JEES (Journal of English Educators 33. https://doi.org/10.21070/jees.v2i1.676.

Irwansyah, D. (2019). Islamic literature: Instructional strategies in contemporary Indonesia. Heritage of Nusantara: International Journal of Religious Literature and Heritage, 8(1), 1-17. https://doi.org/10.31291/hn.v8i1.548.

Islami, M. (2016). Character values and their internalization in teaching and learning $\begin{array}{llll}\text { English at madrasah. Dinamika } I m u, & 16(2), & 279 .\end{array}$ https://doi.org/10.21093/di.v16i2.417.

Jendrych, E., \& Wisniewska, H. (n.d.). ESP: How to design challenging tasks for adult learners. 5.

Karimnia, A., \& Jafari, F. M. (2017). Critical ESP textbook evaluation: The case of visual arts textbook. Sustainable Multilingualism, 11(1), 219-236. https://doi.org/10.1515/sm-2017-0020.

Karman, K. (2017). Developing English reading materials for Madrasah Aliyah students. Langkawi: Journal of The Association for Arabic and English, 3(1), 4562. https://doi.org/10.31332/LKW.V3I1.542.

Kiczkowiak, M. (2019). Seven principles for writing materials for English as a lingua franca. ELT Journal, 1-9. https://doi.org/10.1093/elt/ccz042.

Klimova, B. (2015). Developing tailored-made online materials for academic use. 2015 International Conference on Information Technology Based Higher Education and Training, ITHET 2015. https://doi.org/10.1109/ITHET.2015.7217963.

Kristiyani, C. (2013). An analysis on character education integrated in documents for teaching preparation. Jurnal Penelitian, 16(2). https://ejournal.usd.ac.id/index.php/JP/article/view/773.

Lestariningsih, F. E., Madya, S., \& Nurkamto, J. (2020). Pedagogical problems encountered by teachers of English to Computer Science students in the Indonesian context. EduLite: Journal of English Education, Literature and Culture, 5(1), 1. https://doi.org/10.30659/e.5.1.1-13.

Lodico, M. G., Spaulding, D. T., \& Voegtle, K. H. (2010). Methods in educational research: From theory to practice (Second edi). John Wiley \& Sons, Inc.

McDonough, J., Shaw, C., \& Masuhara, H. (2013). Materials and methods in ELT: A teacher's guide (Third Edit). John Wiley \& Soms, Inc.

Nunan, D. (2010). Task-based language teaching. Cambridge University Press. 
Patel, M. F., \& Jain, P. M. (2008). English language teaching (methods, tools \& techniques). Sunrise Publishers \& Distributors.

Pohan, E. (2014). Character building in language learning and teaching. The 3rd UAD TEFL International Conference, 335-341.

Puspita, W. (2018). Developing English materials for military cadets. Jurnal Pendidikan Bahasa Inggris Indonesia, https://doi.org/10.23887/jpbi.v6i2.2711.

Ratih, I. A. M. (2017). The analysis of classroom character education in English lessons based on the 2013 Curriculum. Journal of Psychology and Instructions, 1(2), 97. https://doi.org/10.23887/jpai.v1i2.10365.

Ratnawati, S. D. (2018). Developing online materials for tour guides. Journal of ELT Research, 3(1), 43. https://doi.org/10.22236/jer_vol3issue1pp43-57.

Richards, J. C. (2006). Materials development and research-making the connection. RELC Journal, 37(1), 5-26. https://doi.org/10.1177/0033688206063470.

Robertson, P. (2018). The Asian EFL Journal July 2018 Volume 20, Issue 7. 263.

Siddiqui, A., Illyas, R., \& Jokhio, R. A. (2017). Defining the role of assessing strategies to evaluate individual language differences within ESP students. International Journal of Language and Literature, 5(2). https://doi.org/10.15640/ijll.v5n2a16.

Sugiyono. (2015). Metode penelitian dan pengembangan (research and development) $R \& D)$. Alfabeta.

Sukirman. (2015). Developing English morphology materials for. ETERNAL (English, Teaching, Learning and Research Journals, 1(1).

Sumarsono, P., Wardhani, A., \& Farah, R. R. (n.d.). The development of authentic English Language Teaching (ELT) textbook of vocational school. 3.

Taridi, M. (2019). Developing English instructional materials to teach descriptive text. 1972-1985. https://doi.org/10.15405/epsbs.2019.08.03.243.

Thresia, F., \& Metro, U. M. (2014). Teaching English based on character education at Senior High School Metro. International Conference on Education and Language, $2,53-59$.

Tomlinson, B. (2005). The future for ELT materials in Asia. Electronic Journal of ELearning 2(2),

$5-13$. https: / / www.google.com/url?sa=t\&rct=j\&q=\&esrc=s\&source=web\&cd=\&cad=rja \&uact $=8$ \&ved $=2$ ahUKEwiWrIGs4ovvAhVMcCsKHT2bBr0QFjAAegQIARAD\&url=ht tps\%3A\%2F\%2Fe-

flt.nus.edu.sg\%2Fv2n22005\%2Ftomlinson.pdf\&usg=AOvVaw3LGBU_mUcFQrlY EeQiy3Vx.

Tomlinson, B. (2010). Principles and procedures of materials development for language learning. 9.

Tomlinson, B., \& Masuhara, H. (2018). The complete guide to the theory and practice of materials development for language learning. John Wiley \& Sons, Ltd.

Trisyanti, U. (2009). Developing materials for ESP (English For Specific Purposes) Class. Jurnal Sosial Humaniora, 2(1). https://doi.org/10.12962/j24433527.v2i1.666.

Umam, C. (2015). Developing instructional materials of English morphology for English department college-learners. Journal on English as a Foreign Language, 5(1), 1. https://doi.org/10.23971/jefl.v5i1.94. 
EduLite Journal of English Education, Literature, and Culture

Vol. 6, No. 1, February 2021, pp. 28-41

E-ISSN: 2528-4479, P-ISSN: 2477-5304

http://jurnal.unissula.ac.id/index.php/edulite

DOI: http://dx.doi.org/10.30659/e.6.1.28-41

Utami, D. N. (2019). Evaluating the communicative materials on ESP book entitled English for international tourism. Language Circle: Journal of Language and Literature, 14(1), 45-58. https://doi.org/10.15294/lc.v14i1.20895.

Villanea Morales, L. (2018). Putting into practice gap tasks in an ESP classroom for medicine personnel at Universidad de Costa Rica. InterSedes, 18(38). https://doi.org/10.15517/isucr.v18i38.32676.

Wilis, J. (1996). A framework for task-based learning (Longman Handbooks for Language Teachers). Addison Wesley Publishing Company.

Yana, D. (2016). Developing English speaking learning materials for Saturday English School Program. ANGLO-SAXON: Jurnal Ilmiah Program Studi Pendidikan Bahasa Inggris, 6(2), 21. https://doi.org/10.33373/anglo.v7i1.492.

Ÿelik, H., \& Topkaya, E. Z. (2016). Evaluation of the methodology of an ESP reading skills course for undergraduate medical students: Outsider perspective. Procedia - Social and Behavioral Sciences, 232, 326-331. https://doi.org/10.1016/j.sbspro.2016.10.030.

Conflict of Interest Statement: The authors declare that the research was conducted in the absence of any commercial or financial relationships that could be construed as a potential conflict of interest.

Copyright (C) 2021 Prayoga, Irwansyah, and Harya. This is an open-access article distributed under the terms of the Creative Commons Attribution License (CC BY). The use, distribution or reproduction in other forums is permitted, provided the original author(s) and the copyright owner(s) are credited and that the original publication in this journal is cited, in accordance with accepted academic practice. No use, distribution or reproduction is permitted which does not comply with these terms. 